\title{
A Computer Assisted Application in Preschool Education: Seasons and Their Characteristics
}

\author{
Nilüfer Okur Akçay \\ Correspondence: Nilüfer Okur Akçay, Faculty of Education, Ağrı İbrahim Çeçen University, Ağrı, 04100, Turkey.
}

Received: January 25, 2016 Accepted: February 27, 2016 Online Published: February 28, 2016

doi:10.11114/jets.v4i3.1332 URL: http://dx.doi.org/10.11114/jets.v4i3.1332

\begin{abstract}
In this study, it is aimed to determine the effect of computer-assisted instruction while teaching the subject seasons to preschool students on the academic success. The sample of the study consists of 86 children from the nursery classes of private and official schools in Ağrı city center. As data collecting tools General Achievement Test used as pre test-post test and Module Tests applied after finishing the subject every week. The collected data is calculated with SPSS 16.0, and descriptive statistics and independent $t$ test are used in the analysis of the data. In the light of the obtained data, it is determined that the academic success of the group on which computer-assisted instruction has been applied is quite higher than the other group's academic success on which traditional instruction has been applied, there is no difference between the success of the school boys or girl, and success is in favor of the students in private schools.
\end{abstract}

Keywords: computer assisted education, preschool, science, seasons

\section{Introduction}

We can feel distinctly the rapid changes in the technology in recent years in every phase of our daily lives. Computers, in the forefront particularly in education environments, have brought the term educational technology along with themselves, and it is argued that using technology in education is beneficial in many ways. Besides computers can be used in almost every field in education, they provide the opportunity to give education to the students at any level. In today's conditions in which the individuals live in technology's pocket, it can be inferred from the conducted study results that using computers in preschool education and implementing education through the computers can be beneficial for the children (Sprigle \& Schaefer, 1984; Clements \& Saramo, 2002; Sancak, 2003; Yaşar, 2004; Kacar, 2006).

Computer-assisted education starts at an early age as much as possible, it will be positive at that rate for the individual to affiliate with the technology. Ar1 and Bayhan (2003) stated that the reasons why educational technology is used in preschool are as the children learn and develop at different rates, become skilled in evaluation and communication, educational technology supports the increase in the quality and quantity in the thinking and writing subjects, it develops the problem solving skills of the children, it improves the sense of art, the children can use the sources at home with educational techniques, educational technologies provides meaningful studying opportunities for the children, the children have the opportunity to meet with advanced technologies, educational technology makes the children feel comfortable while learning, and the schools increase production and their efficacy with educational technology. Allessi and Trollip (1991) are in the opinion that using computers in preschool education is important in terms of the fact that they can be used as an instrument through which the children can interact with each other, children can keep in mind what they've learnt, it provides fluency, and children can be evaluated whether they've learnt the subject being thought or not. The children can also use the computer as an instrument with which they can get information (Li \& Atkins, 2004).

Computers contribute to the education process in preschool education. Various and rich learning environments are presented to the children through using computers, the children are allowed to learn by having fun, using computers gives the opportunity to the children to review the subject they don't understand as much as they want and to reinforce what they've learnt, it contributes the children to develop new methods in problem solving by stimulating the creativity of the children (Alabay, 2006; Chen \& Chang, 2006; Demir, 2007). The main reason why the computers are used in getting information, communicating and having fun is the fact that computers are rich in terms of visual and auditory stimulus. This richness catches the attention of the children and contribute to the hand-eye coordination (using the 
mouse, painting, drawing studies, etc.), problem solving, fast decision making, long term memory, maintaining their attention and acting purposefully if this richness has an educational content (Lankshear \& Knobel, 2003; Tracey \& Young, 2007; Couse \& Chen, 2010; Macaruso \& Rodman, 2011).

Thanks to computers, the creativity and critical thinking skills of the children are improved, children communicate with each other, and they can work together to reach the target (Ghaith \& Yaghi, 1997). And this has positive effects on the children's social development (Haugland, 2000; Scoter, Ellis \& Railsback, 2001; Stevenson \& Hackett, 2009). Besides the computers have advantages, some of the researchers emphasize that the computers can have negative effects on children. Using computers more than necessary, software which is not appropriate for the children's age, spending time in front of the computer without adult supervision can create negative results. According to Okan (2003), as the learning environments are designed using with animations and sounds, the children learn without any trouble, and other learning environments are expected to be designed as so. Besides, that the computers have some negative elements can affect the children's development negatively (Hatzigianni \& Margetts, 2012). The studies conducted in recent years have been focused on how the computers help children's learning and how they do this best (Judge, Puckett \& Cabuk, 2004; Nir-Gal \& Klein, 2004; Penuel et al. 2009). Clements and Samara (2003) determined in their study that the children are quite interested in the subject while using computers and react positively, many teachers can make learning process a lot funnier by using computer activities, and computers have effects which make it easier for the children to learn. While implementing computer-assisted education in preschool education, it should be paid attention that supervision by parents or teachers should be done, the computer should be used in teaching-learning process, the computer should not be used for social media or game purposes, the children should use the computer for formal education purposes, which should be supervised by teachers and parents.

According to Tondeur et al. (2007), using computer in the classroom serves three main purposes. The first of all these is that the skills of the students related to using computer are developed. Other purposes are that the computers provide the students to get information and learn. In this direction, the teachers who use computers in learning environments have big duties. As a matter of fact, the problems occurring in the implementation process of this method were determined in the studies that the teachers have limited or inadequate knowledge and skills about computers and they are inadequate in using computers in preschool activities (Ljung, Bengtsson \& Ottosson, 2005). The fact that the teachers have positive attitudes towards computers during their undergraduate education is affective in solving these problems. In the studies conducted with the preschool preservice teachers related to implementing computer-assisted education, it was found that the preservice teachers have positive attitudes towards this subject, and preschool preservice teacher can use computers effectively as a teaching method in their classes (Oğuz, Ellez, Akamca, Kesercioğlu \& Girgin, 2011; Akçay \& Halmatov, 2015). With the use of computers in teaching-learning process, abstract concepts can become concrete. Abstract concepts can become concrete with the use of the computers in the education process. Computers should be used in preschool education especially for development of the researcher side of characteristics of the children and to create more effective learning environments. Louis Robinson likens the children's learning to use computers as learning to talk and states that the children can learn computer easier and faster than the adults (Ar1 \& Bayhan, 2003).

In the preschool period in which the children start to wonder about what's going on in their environments, science which is a part of our lives should be given the necessary importance and it should be related with the daily life for the children (Eliason \& Jenkins, 2003; Akçay, 2014). Children in the preschool period construct their own knowledge by actively researching the world they live in and they construct the basis of the construction of each information they get (Namlu, 2002; Tuğrul, 2005; Aktaş, 2007; Kandır \& Orçan, 2010). Science education is necessary for the preschool children in terms of being able to think critically more, finding different solutions to the problems, being able to make comparisons of different events, developing their observation skills and increasing their attention span (Bredekamp \& Copple, 1997). With a science class which would be conducted with a computer, it becomes possible that the children have the opportunities that a computer provides to the education. Turkey has a location in which four seasons are experiences because of geographic conditions. It is quite important in direction of the science class aims that understanding the features of the seasons spring, summer, fall and winter which the children find the opportunity in the environments to observe. In this study, seasons subject was dealt and it was aimed that the children learn the features of the seasons. According to the literature view, the effect of computer-assisted education on different courses and subjects were done before (Lui, 1997; Şahin, 2006; Kacar \& Doğan, 2007; Ayvacı \& Devecioğlu, 2010), however, no study has been conducted about seasons. In this direction, answers to the questions below are sought.

1. Does the computer-assisted education have effect on the children's learning of seasons subject?

2. Is there a difference between the academic success of male and female students in teaching the subject of seasons?

3. Is there difference between the schools the children get educated in teaching the subject of seasons? 


\section{Method}

In this study, the effectivity of computer-assisted education on teaching of seasons subject to the 5-6 year-old children in nursery class. The study is in the model of semi-experimental study with pretest-posttest repetitive measurements and with experiment and control groups.

\subsection{Research Group}

The sample of this study consists of 86 nursery class children (average of age: 66 month-72 month) from two different preschools (school A: private, school B: official) in Ağrı city center in fall term of 2014-2015 academic years. Data related to the sample of the study is indicated in Table 1. Two groups as Computer-Assisted Education Group (CAEG) and Control Group (CG) in both schools were created randomly.

Table 1. Data related to the Sample of the Study

\begin{tabular}{lcccc} 
& \multicolumn{3}{c}{ Preschools } \\
\cline { 2 - 5 } Gender & A (private) & \multicolumn{2}{c}{ B (official) } \\
\hline Female & 10 & 12 & CAEG & CG \\
Male & 12 & 8 & 16 & 8 \\
Total & 22 & 20 & 10 & 10 \\
\hline
\end{tabular}

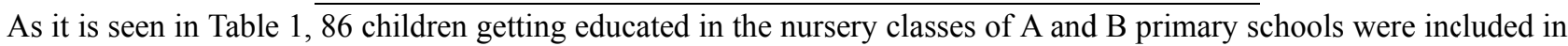
the study. 48 of these children were in computer-assisted education group and 38 of them were in traditional education group. 22 females and 20 males from school A and 24 females and 20 males from school B participated in the study. It was paid attention that the number of the male and female students in each group was close to each other.

\subsection{Data Collection Tools}

In the direction of this study, data collecting instruments were developed by the researcher by asking the opinions of two assistant professors and two teachers. General achievement test and module testing were used as data collection tools in the study. Pilot study was first conducted in the development of the achievement test and then the reliability and validity analysis of the test (Croanbachs' alpa $=.72$ ) were done and the last form of the test was used in the study. General achievement test was used as pretest-posttest in the study. Module testing (Croanbachs' alpa MT1=.70; $M T 2=.75 ; M T 3=.77 ; M T 4=.69 ; M T 5=.79$ ) was conducted at the end of weekly subjects. The information related to the content of the module testing is indicated in the Table 2.

Module 1 and Module 2 testing sample are indicated in the figure below.
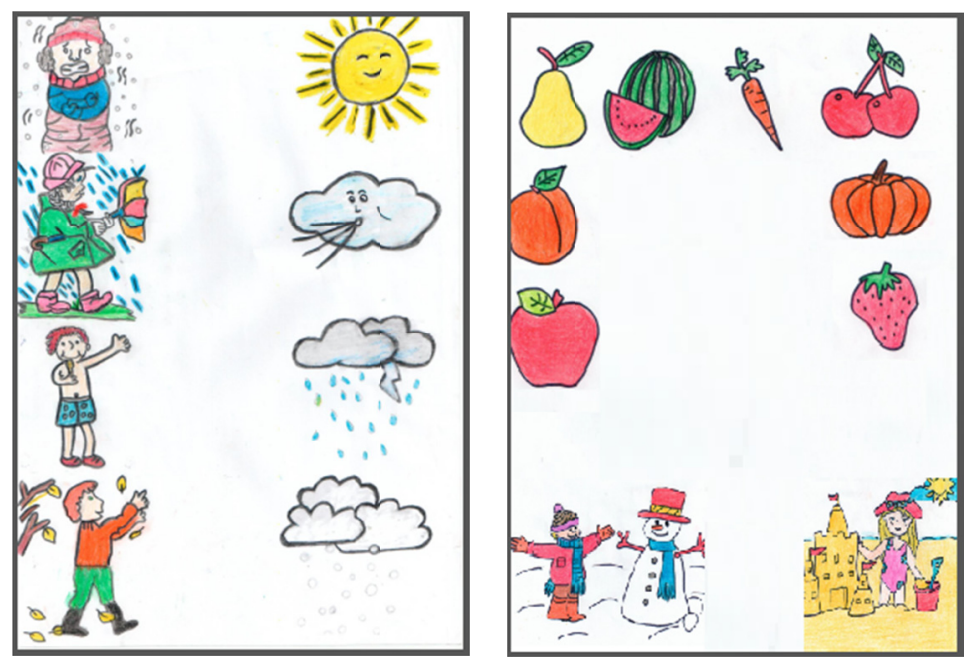

Figure 1. Module 1 (left) and Module 2 (right) Testing Sample

Table 2. The Content Information of the Module Testing

\begin{tabular}{cl}
\hline Module Testing & \multicolumn{1}{c}{ Content } \\
\hline Module 1 & Matching the clothes with weather forecast \\
Module 2 & Matching the food belonging to summer and winter \\
Module 3 & Drawing summer and winter clothes \\
Module 4 & Expressing the features of four different seasons \\
Module 5 & Matching things related to four different seasons (food-beverages-clothes) \\
\hline
\end{tabular}




\subsection{Implementation Process}

Teaching of the seasons subject to nursery class students was conducted in 5 weeks. In the data collection process, each child was taken care of separately. In the teaching process, computer-assisted education was implemented in one group and traditional education was implemented in the other group.

\subsubsection{Teaching with CAE}

Before starting to teach with computer, the teacher explained necessary information and rules related to the aims. In the computer-assisted teaching activities, the game that was to play on that day was determined by the teachers and the instruction which was given by the computer was followed. The teacher explained again what was asked when needed. The researcher prepared animations and activities by using Macromedia Flash MX software. In the prepared activities, the children were given verbal prizes such as "well done, you did it right", "nicely done", congratulations" when they conducted the tasks correctly in the child games; and they were given verbal notifications such as "no, you did it wrong", "no, try again" when they did it wrong, and the children were encouraged to play the games once more. In the situations when the children could not fulfill the task in the games, they were waited to fulfill the task for a few times, and if he could not have done it, they were helped and the child was provided to do it himself and then the following activity was dealt. Figure 2 indicates the activity examples.
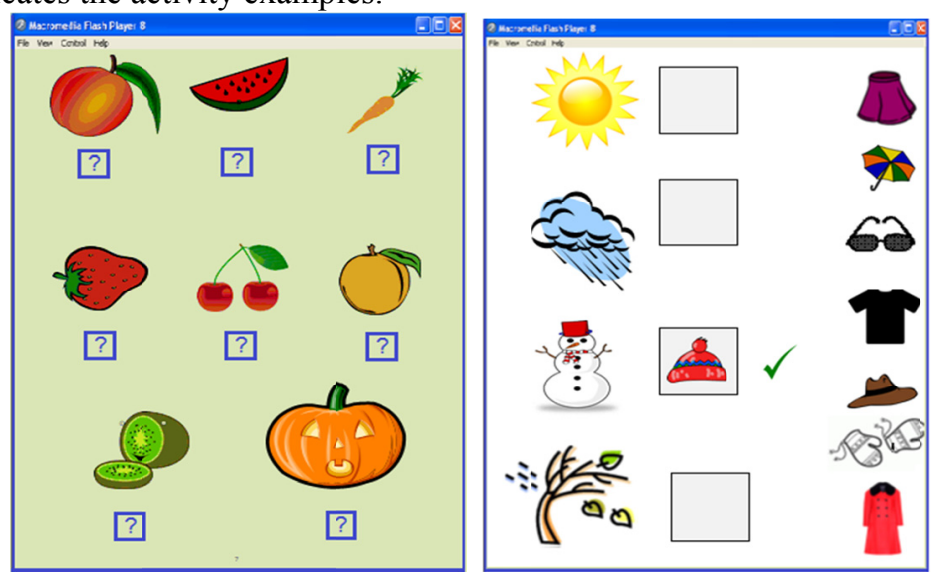

Figure 2. The screenshots of the animations used in CAE groups.

\subsubsection{Teaching with Traditional Method}

While the seasons subject was being taught in the class where education took place with traditional method, the teacher became a model for the children and he decided what the children did during the learning process. The teacher planned the activities and he provided that the children did the activities. As parallel with the experimental group, different activities were prepared through each week.

\subsection{Analysis of the Data}

The obtained data was analyzed by using SPSS 16.00 and descriptive statistics and independent t-test were used in the analyses of the data.

\section{Findings}

The graphic related to the results of the pretest and posttest conducted in the schools participating in the study is indicated below.

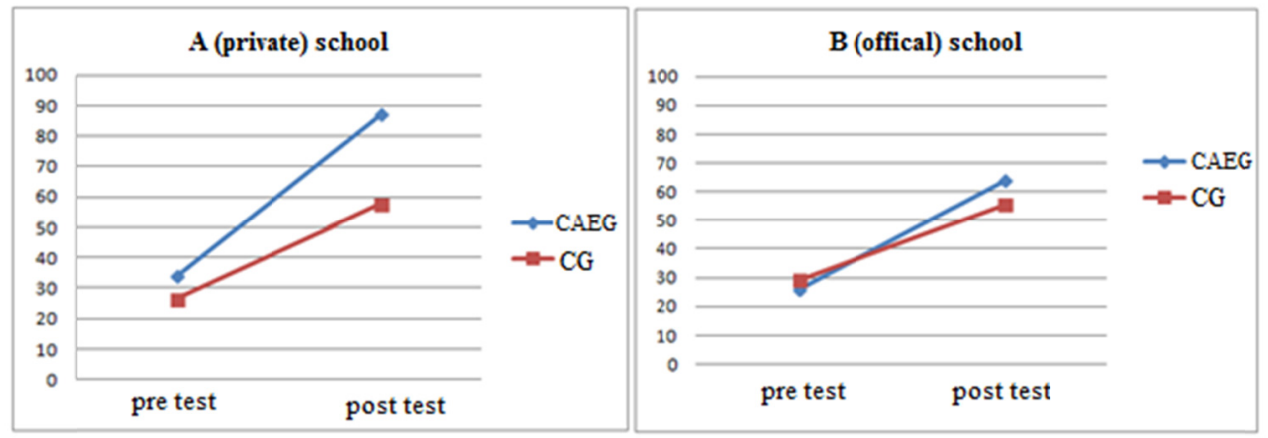

Figure 3. The pretest and posttest results of A and B schools 
As a result of the analysis in school A, it was determined that the arithmetic mean of the pretest of CAEG was 33.9 and the standard deviation was 13.58; the arithmetic mean of CG was 26.6 and the standard deviation was 11.31; and the difference between them was not significant $(\mathrm{t}(40)=1.884 ; \mathrm{p}>0.05)$. In addition, it was determined that the arithmetic mean of the posttest results of CAEG was 87.27 and standard deviation was 11.05, the arithmetic mean of CG was 57.80 and the standard deviation was 11.21 , and the difference between them was a significant $(\mathrm{t}(40)=7.06 ; \mathrm{p}<0.05)$. In school B, it was determined that the arithmetic mean of the pretest of CAEG was 26.0 and the standard deviation was 10.1; the arithmetic mean of CG was 29.3 and the standard deviation was 12.51, and the difference between them was not significant $(\mathrm{t}(42)=-.799 ; \mathrm{p}>0.05)$. In addition, it was determined that the arithmetic mean of the posttest results of CAEG was 63.84 and the standard deviation was 10.02; the arithmetic mean of CG was 55.5 and the standard deviation was 10.34, and the difference between them was significant $(\mathrm{t}(42)=2.66 ; \mathrm{p}<0.05)$. The pretest and posttest results of the nursery class children from the general achievement test according to the education type are indicated in Table 3.

Table 3. The results of pretest-posttest independent t-test according to groups

\begin{tabular}{lcccccc}
\hline Tests & Groups & $\mathrm{N}$ & $\mathrm{X}$ & $\mathrm{sd}$ & $\mathrm{t}$ & $\mathrm{p}$ \\
\hline Pretest & CAEG & 48 & 29.62 & 12.36 & .598 & .551 \\
& CG & 38 & 27.89 & 14.44 & & \\
\hline Posttest & CAEG & 48 & 74.58 & 14.72 & 5.59 & .000 \\
& CG & 38 & 56.73 & 13.34 & & \\
\hline
\end{tabular}

On analyzing the Table 3, it is seen that the arithmetic mean of the pretest results of the CAEG was 29.62 and the standard deviation was 12.36; the arithmetic mean of CG was 27.89 and the standard deviation was 14.44, and the difference between them was not significant $(\mathrm{t}(84)=.598 ; \mathrm{p}>0.05)$. It is seen that the arithmetic mean of the posttest result of CAEG was 74.58 and the standard deviation was 14.72, the arithmetic mean of CG was 56.73 was 14.72 , and the difference between them was significant $(\mathrm{t}(84)=5.59 ; \mathrm{p}<0.05)$. The data related to the module testing which was applied at the end of the subjects each week is indicated in the graphics and tables below.

$\because \mathrm{CAEG} \quad \mathrm{CG}$

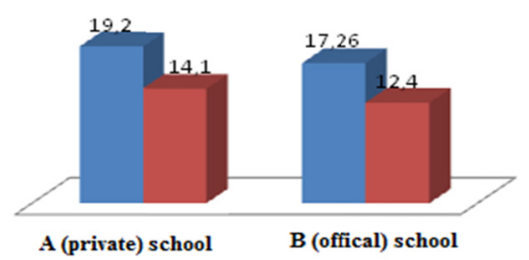

Figure 4. The results of module testing 1 related to school A and B

As a result of the analyses, in school A, the arithmetic mean of the module testing 1 results of CAEG was determined as 19.2 and the standard deviation as 4.01, the arithmetic mean of CG was determined as 14.1 and the standard deviation as 6.20 , and it is seen that the difference between them is significant $(\mathrm{t}(40)=.621 ; \mathrm{p}<0.05)$. In school $\mathrm{B}$, it was determined that the arithmetic mean of the module testing 1 results of CAEG was 17.26 and the standard deviation was 6.08 , the arithmetic mean of CG was 12.4 and the standard deviation was 10.29 , and the difference between them was significant; which can be seen in Figure $4(\mathrm{t}(42)=1.12 ; \mathrm{p}<0.05)$. Table 4 indicates the general achievement test results of CAEG and CG.

Table 4. Data related to the results obtained from module testing 1

\begin{tabular}{cccccc}
\hline Groups & $\mathrm{N}$ & $\mathrm{X}$ & $\mathrm{sd}$ & $\mathrm{t}$ & $\mathrm{p}$ \\
\hline CAEG & 48 & 18.23 & 5.04 & .702 & .000 \\
CG & 38 & 13.05 & 8.25 & &
\end{tabular}

According to the results of module testing 1, it can be seen in Table 4 that the arithmetic mean of the CAEG was 18.23 and the standard deviation was 5.04, and the arithmetic mean of CA was 13.05 and the standard deviation was 8.25, and the difference between them was significant $(\mathrm{t}(84)=.702 ; \mathrm{p}<0.05)$.

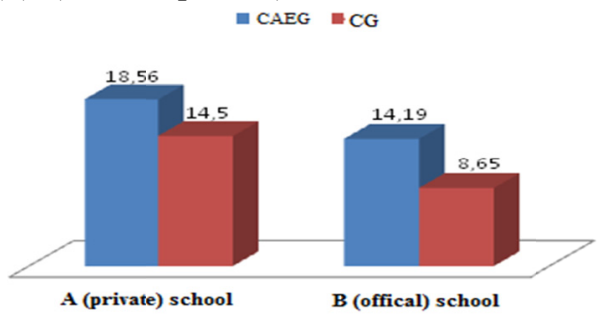

Figure 5. The results of module testing 2 related to school A and B 
As a result of the analyses, in school A, the arithmetic mean of the module testing 2 results of CAEG was determined as 18.56 and the standard deviation as 6.01, the arithmetic mean of CG was determined as 14.5 and the standard deviation as 4.20 , and it is seen that the difference between them is significant $(\mathrm{t}(40)=2.21 ; \mathrm{p}<0.05)$. In school $\mathrm{B}$, it was determined that the arithmetic mean of the module testing 2 results of CAEG was 14.19 and the standard deviation was 8.98 , the arithmetic mean of CG was 8.65 and the standard deviation was 6.85 , and the difference between them was significant; which can be seen in Figure $5(\mathrm{t}(42)=.712 ; \mathrm{p}<0.05)$. Table 5 indicates the general achievement test results of CAEG and CG.

Table 5. Data related to the results obtained from module testing 2

\begin{tabular}{cccccc}
\hline Groups & $\mathrm{N}$ & $\mathrm{X}$ & $\mathrm{sd}$ & $\mathrm{t}$ & $\mathrm{p}$ \\
\hline CAEG & 48 & 16.37 & 7.58 & 1.51 & .000 \\
CG & 38 & 11.54 & 5.63 & & \\
\hline
\end{tabular}

According to the results of module testing 2, it can be seen in Table 5 that the arithmetic mean of the CAEG was 16.37 and the standard deviation was 7.58, and the arithmetic mean of CA was 11.54 and the standard deviation was 5.63, and the difference between them was significant $(\mathrm{t}(84)=1.51 ; \mathrm{p}<0.05)$.

$$
\because \mathrm{CAEG} \backsim \mathrm{CG}
$$

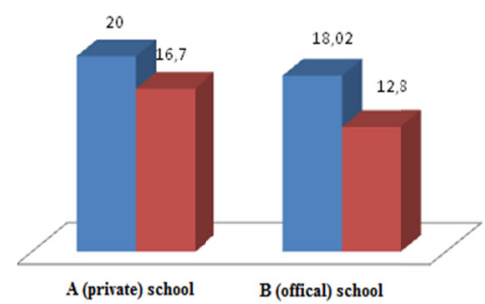

Figure 6. The results of module testing 3 related to school A and B

As a result of the analyses, in school A, the arithmetic mean of the module testing 3 results of CAEG was determined as 20 and the standard deviation as 7.65, the arithmetic mean of CG was determined as 16.7 and the standard deviation as 7.28 , and it is seen that the difference between them is significant $(\mathrm{t}(40)=1.36 ; \mathrm{p}<0.05)$. In school $\mathrm{B}$, it was determined that the arithmetic mean of the module testing 3 results of CAEG was 18.02 and the standard deviation was 9.28 , the arithmetic mean of CG was 9.14 and the standard deviation was 6.85, and the difference between them was significant; which can be seen in Figure $4(\mathrm{t}(42)=.562 ; \mathrm{p}<0.05)$. Table 5 indicates the general achievement test results of $\mathrm{CAEG}$ and CG.

Table 6. Data related to the results obtained from module testing 3

\begin{tabular}{cccccc}
\hline Groups & $\mathrm{N}$ & $\mathrm{X}$ & $\mathrm{sd}$ & $\mathrm{t}$ & $\mathrm{p}$ \\
\hline CAEG & 48 & 19.01 & 8.48 & 2.07 & .000 \\
CG & 38 & 14.87 & 8.16 & & \\
\hline
\end{tabular}

According to the results of module testing 3, it can be seen in Table 6 that the arithmetic mean of the CAEG was 19.01 and the standard deviation was 8.48, and the arithmetic mean of CA was 14.87 and the standard deviation was 9.16, and the difference between them was significant $(\mathrm{t}(84)=2.07 ; \mathrm{p}<0.05)$.

$$
\because \mathrm{CAEG} \backsim \mathrm{CG}
$$

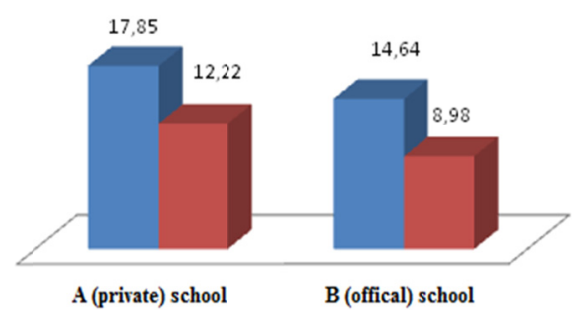

Figure 7. The results of module testing 4 related to school A and B

As a result of the analyses, in school $\mathrm{A}$, the arithmetic mean of the module testing 4 results of CAEG was determined as 17.85 and the standard deviation as 7.11, the arithmetic mean of CG was determined as 12.22 and the standard deviation as 7.14, and it is seen that the difference between them is significant $(t(40)=2.67 ; \mathrm{p}<0.05)$. In school $\mathrm{B}$, it was determined that the arithmetic mean of the module testing 4 results of CAEG was 14.64 and the standard deviation was 6.57, the arithmetic mean of CG was 8.98 and the standard deviation was 10.36, and the difference between them was significant; which can be seen in Figure $7(\mathrm{t}(42)=1.03 ; \mathrm{p}<0.05)$. Table 7 indicates the general achievement test results of CAEG and CG. 
Table 7. Data related to the results obtained from module testing 4

\begin{tabular}{cccccc}
\hline Groups & $\mathrm{N}$ & $\mathrm{X}$ & $\mathrm{sd}$ & $\mathrm{t}$ & $\mathrm{p}$ \\
\hline CAEG & 48 & 15.98 & 6.84 & .412 & .000 \\
CG & 38 & 10.65 & 8.75 & & \\
\hline
\end{tabular}

According to the results of module testing 4, it can be seen in Table 7 that the arithmetic mean of the CAEG was 15.98 and the standard deviation was 6.84, and the arithmetic mean of CG was 10.65 and the standard deviation was 8.75 , and the difference between them was significant $(\mathrm{t}(84)=.412 ; \mathrm{p}<0.05)$.

$$
\square \mathrm{CAEG} \square \mathrm{CG}
$$

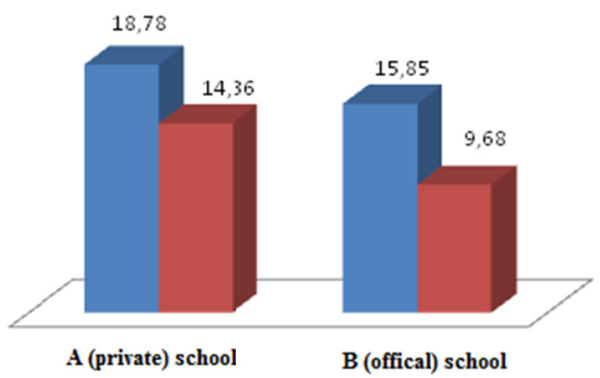

Figure 8. The results of module testing 5 related to school A and B

As a result of the analyses, in school A, the arithmetic mean of the module testing 5 results of CAEG was determined as 18.78 and the standard deviation as 6.85 , the arithmetic mean of CG was determined as 14.36 and the standard deviation as 9.48, and it is seen that the difference between them is significant $(\mathrm{t}(40)=3.59$; $\mathrm{p}<0.05)$. In school $\mathrm{B}$, it was determined that the arithmetic mean of the module testing 5 results of CAEG was 15.85 and the standard deviation was 11.07, the arithmetic mean of CG was 9.68 and the standard deviation was 12.02, and the difference between them was significant; which can be seen in Figure $7(\mathrm{t}(42)=.877 ; \mathrm{p}<0.05)$. Table 8 indicates the general achievement test results of CAEG and CG.

Table 8. Data related to the results obtained from module testing 5

\begin{tabular}{cccccc}
\hline Groups & $\mathrm{N}$ & $\mathrm{X}$ & $\mathrm{sd}$ & $\mathrm{t}$ & $\mathrm{p}$ \\
\hline CAEG & 48 & 18.31 & 8.96 & 2.15 & .000 \\
CG & 38 & 12.02 & 10.75 & & \\
\hline
\end{tabular}

According to the results of module testing 5, it can be seen in Table 8 that the arithmetic mean of the CAEG was 18.31 and the standard deviation was 8.96, and the arithmetic mean of CG was 12.02 and the standard deviation was 10.75 , and the difference between them was significant $(\mathrm{t}(84)=2.15 ; \mathrm{p}<0.05)$. The Figure 9 indicates data whether there was a significant difference among the children in terms of gender.

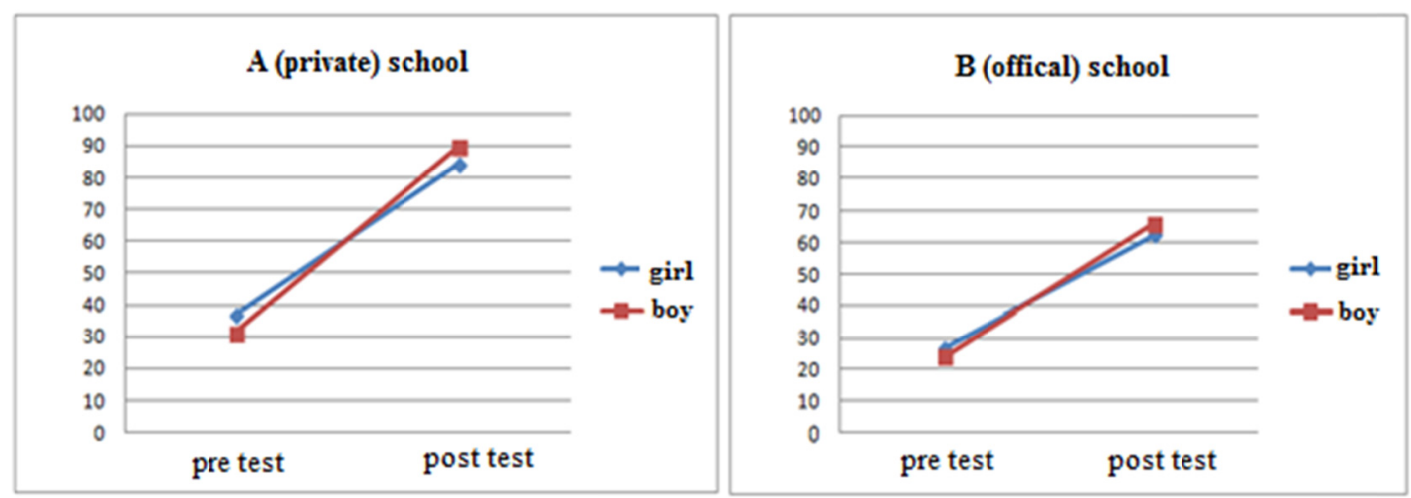

Figure 9. The success status of the CAE in terms of gender in schools A and B

It is seen that the arithmetic mean of the pretest results of the female students who got educated with CAE in school A was 37 and the standard deviation was 17.39; the arithmetic mean of the male students was 31.3 and the standard deviation was 9.43, and the difference between them was not significant $(t(20)=.973 ; p>0.05)$. And also the arithmetic mean of the post test results of the female students was 84.2 and the standard deviation was 13.61 ; the arithmetic mean of the male students was 89.83 and the standard deviation was 8.11, and the difference between them was not significant $(\mathrm{t}(20)=-1.203 ; \mathrm{p}>0.05)$.

It is seen in Figure 9 that the arithmetic mean of the pretest results of the female students who got educated with CAE in school B was 27 and the standard deviation was 10.78; the arithmetic mean of the male students was 24.4 and the 
standard deviation was 9.32, and the difference between them was not significant $(\mathrm{t}(24)=.629 ; \mathrm{p}>0.05)$. And also the arithmetic mean of the post test results of the female students was 62.5 and the standard deviation was 9.89 ; the arithmetic mean of the male students was 66 and the standard deviation was 10.37, and the difference between them was not significant $(\mathrm{t}(24)=-.862 ; \mathrm{p}>0.05)$. Overall scores of the boys and girls are given in Table 9.

Table 9. The pretest-posttest independent t-test results of the male and female student

\begin{tabular}{lcccccc}
\hline Tests & Gender & $\mathrm{N}$ & $\mathrm{X}$ & $\mathrm{sd}$ & $\mathrm{t}$ & $\mathrm{p}$ \\
\hline Pretest & Girls & 26 & 30.84 & 14.25 & .740 & .463 \\
& Boys & 22 & 28.18 & 9.81 & & \\
\hline Posttest & Girls & 26 & 70.84 & 15.53 & -1.83 & .073 \\
& Boys & 22 & 79 & 15.10 & & \\
\hline
\end{tabular}

On analyzing Table 9 , it is seen that the arithmetic mean of the pretest results of the female students was 30.84 and the standard deviation was 14.25 , and the arithmetic mean of the pretest results of the male students was 28.18 and the standard deviation was 9.81, and the difference between them was not significant $(\mathrm{t}(46)=.740 ; \mathrm{p}>0.05)$. And it is seen that the arithmetic mean of the post test results of the female students was 70.84 and the standard deviation was 15.53 , and the arithmetic mean of the post test results of the male students was 79 and the standard deviation was 15.10 , and the difference between them was not significant $(\mathrm{t}(46)=-1.83 ; \mathrm{p}>0.05)$. Figure 10 indicates whether there was a significant difference among the school types of the students participating in the study.

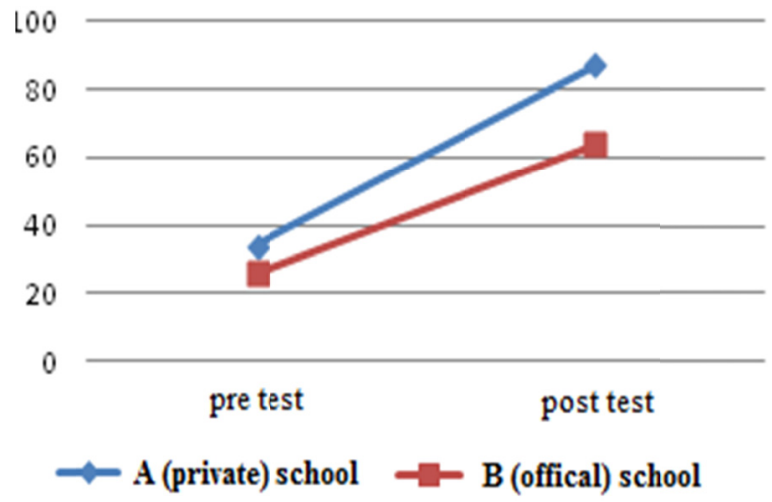

Figure 10. The comparison of the pretest and posttest achievement scores of the CAE groups in terms of school type

As it seen Figure 10 that a result of the analyses it was determined that the arithmetic mean of the pretest of A school was 33.9 and the standard deviation was 13.58; the arithmetic mean of B school was 26 and the standard deviation was 10.13; and the difference between them was significant $(\mathrm{t}(46)=2.30 ; \mathrm{p}<0.05)$. And also that a result of the analyses it was determined that the arithmetic mean of the post test of A school was 87.27 and the standard deviation was 11.05; the arithmetic mean of B school was 63.84 and the standard deviation was 10.02; and the difference between them was significant $(\mathrm{t}(46)=7.69 ; \mathrm{p}<0.05)$.

\section{Discussion and Conclusion}

In this study, it was aimed to determine the effectivity of computer-assisted education on teaching seasons subject to the students and it was determined that the academic success of the group on which computer-assisted education was conducted is quite higher than the group's on which traditional education method was conducted in the light of the results obtained as a result of the study. When reviewing the studies on the effectivity of computer-assisted education in preschool, it is seen that computer-assisted education increases the success. Kaçar and Doğan (2010) analyzed the difference between computer-assisted education and traditional teaching method in teaching the geometric figures and number concepts in terms of academic success in their study and they determined as a result of the study that the group which got educated with computer-assisted education is more successful than the group which got educated with traditional teaching method. Sandberg (2002) analyzed the effects of computer games on defining the concepts and child development in their study conducted on preschool teachers, and he determined that the computer has an important role on child development. Sancak (2003) analyzed the effects of computer-assisted education and traditional teaching method on bringing the six-year children continuing preschool institutions in the number and figure concepts, and he determined that the students got educated with computer-assisted education are more successful than the students got educated with traditional teaching method. Demir (2007) dealt with color concepts and he determined that teaching the color concept with computer-assisted education is superior to teaching the subject with traditional teaching method. Alabay (2006) conducted a study analyzing the effectivity of computer-assisted education on teaching the mathematical concepts to preschool children and determined that the children got educated with computer-assisted education are quite successful compared to those got educated with traditional teaching method. Crawford (2000) analyzed the effect of 
computer on the social behaviors of the preschool children and stated that the computer has positive effects on the social behaviors of the children. San and Ar1 (1988) investigated the effects of computer-assisted education on teaching number and amount subjects and determined as a result of the study that teaching with computer-assisted education is more effective than the teaching with traditional teaching method. Şahin (2006) analyzed the effectivity of teaching some of the science subjects (plants, animals, heat, our body, air, water, sound, light) via computer-assisted education and determined that computer assisted education is more effective in academic success and remembering, in addition teaching with computer-assisted education increases the motivation of the science teaching program students, it affects positively gaining basic knowledge and skills related to science, it improves problem solving, collaboration and helping skills, it affects positively the attention span, the interest of the students towards the course and gaining basic knowledge and skills.

The children, in general, cannot generalize the method they use to solve a problem to other situations. Children who use computers use various methods for different problems and each time they discover the method themselves and apply it. This provides the children to generalize the method. With computer, the children learn by doing and experiencing, and this makes the learning to be permanent and natural. With computer-assisted education, the children can participate in the process of learning and they can comprehend not only the knowledge and skills but how to think and learn as well. Computer-assisted education provides the children the opportunity to discover freely the different solutions without the fear of being unable to do (Ar1 \& Bayhan, 2003). For a better understanding of the mentioned features, the children were asked to think freely and draw pictures about seasons within the study. On analyzing the pictures drawn by the students, it can be seen that the students in CAEG drew more colorful, more understandable and more creative pictures compared to those in CG. Below are the pictures of the students from computer-assisted education and traditional teaching groups.

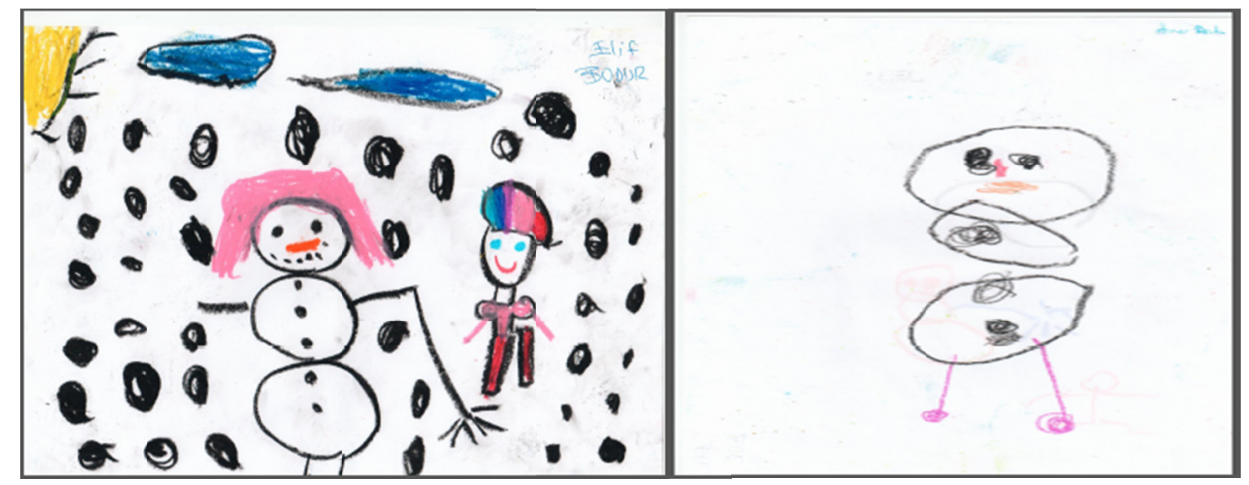

Figure 11. The pictures of the students of CAEG (left) and CG (right) about winter

When Figure 11 is analyzed, it is seen that the picture drawn by the CAEG student has more visual richness compared to the one drawn by the CG student. It can be said that the reason of this is because the computer provides rich stimulus related to winter and improves the imagination of the children and makes them more creative. In the study conducted with Fletcher-Flinn and Gravatt (1995), it was stated that computer-assisted education is more effective in mathematics, science, art, reading and writing skills of the children than traditional teaching method.

As a result of the data obtained through the study, it was determined that there is no significant difference between the academic success of male and female students. In the studies in which computer-assisted education was analyzed in terms of gender, similar results were determined (Passig \& Levin, 1999; Wilson, 2004). Another result obtained from the study shows that there is significant difference between the academic success of the students in terms of the school type they get educated in and this difference is in favor of private schools. The reason why private schools are more successful is that the materials used in education are rich, the students have better socio-economic conditions, and the education levels of the parents are higher-up. It was determined that CAE group is more successful than the CG as a result of the analysis of the conducted Module testing at the end of subjects each week, and the success is in favor of private school.

According the results of the study, a more concrete and effective teaching was done in teaching the seasons subject with computer-assisted education and it is expected that this method can show positive effect on academic success when used in teaching other science subject. To train a better science literate individual, the teachers should also have knowledge about the science subjects. But during the interviews conducted through the study, it was seen that the preschool teachers consider themselves inadequate in science subjects. The views of the teachers about this can be seen below:

T1: "I don't consider myself adequate in science subjects at all, thus I hesitate to do science activities, the children try to ask everything they see in their environments and I mostly have difficulty in responding them." 
T2: "I experience difficulty in finding experiments and activities about science subjects from the books and internet, however, when I conduct an experiment in the classroom, the children ask different questions and I can say that I have difficulty in answering these questions."

As a result of the interviews done with the preschool teachers during the study, it was determined that the teachers concentrate on different activities instead of science activities and the children get educated lack of scientific skills which is gained via science class. The teachers can bring science into the classroom by utilizing the materials such as animations and simulations prepared for education purposes via computers. As the computer is a tool that increases the motivation and interest of the children, it is important to use it in the classroom as a teaching and learning tool (Aktaş-Arnas, 2005; Vorkapić \& Milovanović, 2012; Balat et al. 2015; Bird \& Edwards, 2015). Besides, the teachers can show the experiments through the computers without giving up doing experiments when they cannot supply materials. In this way, the teaching and learning can be accomplished without any cost. It was revealed that the preschool teachers do not use computer-assisted education in teaching the basic science subjects as a result of the conducted studies (Vernadakis et al. 2005; Akçay, 2015). It is a fact that the children learn faster and better with computer. Thus, the teachers should always keep in their mind that they can conduct a more effective teaching with computers (Vernadakis et al. 2005). According to the obtained data, it was determined that materials prepared with computers are more effective in increasing the success of the students. Materials provided the children the opportunity for self-learning and the children get information about seasons appropriate to their learning speed. Concepts related to seasons are made concrete thanks to computers and that the children use these concepts in their daily lives increased, and they achieved a more permanent and a more associable learning compared to the children in the group in which traditional teaching methods was conducted. Because the children consider the computers as a funny and interesting gaming tool more than a learning tool and thus they have positive attitudes towards computers. This makes the academic success to increase. In this direction, the preschool teachers should be supported by giving them seminars and courses to use computers in their classes actively. Besides, the teachers who consider themselves inadequate about science subjects should be given supportive science training and their knowledge levels should be increased.

\section{References}

Akçay, N. O. (2015). Okul öncesi öğretmen adaylarının fen öğretimi öz yeterlik inançlarının çeşitli değişkenlere göre incelenmesi. Route Educational\&Social Science Journal, 2(4), 268-275. http://dx.doi.org/10.17121/ressjournal.448

Akçay, N. O., \& Halmatov, M. (2015). Okul öncesi öğretmen adaylarının bilgisayar destekli eğitim yapmaya ilişkin tutumlarının incelenmesi. Trakya Üniversitesi Eğitim Fakültesi Dergisi, 5(1), 44-50.

Aktaş, A. Y. (2005). Okul öncesi dönemde bilgisayar destekli eğitim. Eğitim Araştırmaları Dergisi, 20, 36-47.

Aktaş, Y. A. (2007). Okul öncesi çocuklarda gelişim ve öğrenme, okul öncesi dönemde fen eğitimi. Ankara: Kök Yayıncilik.

Alabay, E. (2006). Altı yaşs okul öncesi dönemi çocuklarına bilgisayar destekli matematiksel kavramların ögretimi. Yayınlanmamış Yüksek Lisans tezi. Selçuk Üniversitesi, Sosyal Bilimler Enstitüsü, Konya.

Alessi, S. M., \& Trollip, S. R. (1991). Computer-Based Instruction: Medhods and Development. New Jersey Prentice-Hall:Englewood Cliffs.

Arı, M. V., \& Bayhan, P. (2003). Okulöncesi dönemde bilgisayar destekli eğitim. İstanbul: Epsilon Yayınc1lı.

Ayvac1, H. Ş., \& Devecioğlu, Y. (2010). Computer-assisted instruction to teach concepts in pre-school education. Innovation and Creativity in Education, 2(2). 2083-2087. http://dx.doi.org/10.1016/j.sbspro.2010.03.285

Balat, G. U., Dağal, A. B., \& Kanburoğlu, V. (2015). The Effect of Computer Aided Education Program on the Development of Concept in 48-60 Months Children. Procedia-Social and Behavioral Sciences, 176, 20-26. http://dx.doi.org/10.1016/j.sbspro.2015.01.439

Bird, J., \& Edwards, S. (2015). Children learning to use technologies through play: A Digital Play Framework. British Journal of Educational Technology, 46(6), 1149-1160. http://dx.doi.org/10.1111/bjet.12191

Botha, L., \& Reddy, C. (2011). In-service teachers' perspectives of pre-service teachers' knowledges of science. South African Journal of Education, 31(2), 257-274.

Bredekamp, S., \& Copple, C. (Eds.) (1997). Developmentally appropriate practice in early childhood programs (Rev. ed.). Washington, DC: National Association for the Education of Young Children.

Chen, J., \& Chang, C. (2006). Using computers in early childhood classrooms: Teachers' attitudes, skills and practices. Journal of Early Childhood Research, 4(2), 169-188. http://dx.doi.org/10.1177/1476718X06063535

Clements, D. H., \& Samara, J. (2003). Strip mining for gold: Research and policy in educational technology a response 
to "Fool's Gold". Association for the Advancement of Computing in Education Journal, 11(1), 7-69.

Clements, D. H., \& Saramo, J. (2002). The role of technology in early childhood learning. Teaching Children Mathematics, 8(6), 340-344.

Couse, L. J., \& Chen, D. W. (2010). A tablet computer for young children? Exploring its viability for early childhood education. International Society for Technology in Education, 43(1), 75-98. http://dx.doi.org/10.1080/15391523.2010.10782562

Crawford, C. (2000). Impacting learning environments from prekindergarten through graduate school: Technologically appropriate Professional development and classroom integration opportunities for educators. In D.A. Willis, J.Price \& J. Willis (Eds.), Society for information technology \&teacher education international conference (pp. 601-603). Chesapeake, VA, USA: AACE.

De Villiers, R. (2011). Student teachers' views: what is an interesting Life Sciences curriculum? South African Journal of Education, 31, 535-548.

Demir, N. (2007). Okul öncesi öğrencilerine renk kavramının kazandırllmasında bilgisayar destekli ve geleneksel öğretim yöntemlerinin karşılaştırılması. Yayımlanmamış Yüksek Lisans Tezi, Selçuk Üniversitesi, Sosyal Bilimler Enstitüsü, Konya.

Demirbaş, M., \& Ertuğrul, N. (2014). A study on preschoolers' conceptual perceptions of states of matter: a case study of Turkish students. South African Journal of Education, 34(3), 1-13. http://dx.doi.org/10.15700/201409161115

Eliason, C., \& Jenkins, L. (2003). A practical guide to early childhood curriculum. Ohio: Merrill Prentice Hall.

Fletcher, F., Claire, M., \& Gravatt, B. (1995). The efficacy of computer assisted instruction (cai): a meta-analysis. Journal of Educational Computing Research, 12(3), 219-241. http://dx.doi.org/10.2190/51D4-F6L3-JQHU-9M31

Ghaith, G., \& Yaghi, H. (1997). Relationships among experience, teacher efficacy, and attitudes toward the implementation of instructional innovation. Teaching and Teacher Education, 13(4), 451-458. http://dx.doi.org/10.1016/S0742-051X(96)00045-5

Hatzigianni, M., \& Margetts, K. (2012). I am very good at computers: Young children's computer use and their computer self- esteem. European Early Childhood Education Research Journal, 20(1), 3-20. http://dx.doi.org/10.1080/1350293X.2012.650008

Haugland, S. W. (2000). What role should technology play in young children's learning? Part 2. Early childhood classrooms for the 21 st century. Using computers to maximize learning. Young Children, 55(1), 12-18.

Judge, S., Puckett, K., \& Cabuk, B. (2004). Digital equity: New findings from the early childhood longitudinal study. Journal of Research on Technology in Education, 36(4), 383-396. http://dx.doi.org/10.1080/15391523.2004.10782421

Kacar, A. Ö. (2006). Okul öncesi eğitimde bilgisayar destekli eğitimin rolü. Yayımlanmamış Yüksek Lisans tezi, Gazi Üniversitesi Fen Bilimleri Enstitüsü, Ankara, Türkiye.

Kacar, A. Ö., \& Doan, N. (2007). Okulöncesi eğitimde bilgisayar destekli eğitimin rolü. Akademik Bilişim, 2007. Dumlupınar Üniversitesi, Kütahya.

Kacar, A. O., \& Dogan, N. (2010). The role of computer aided education in pre-school education. e-Journal of New World Sciences Academy NWSA, 5, 472-484.

Kandır, A., \& Orçan, M. (2010). Okul öncesi dönemde matematik eğitimi. İstanbul: Morpa Kültür Yayınları.

Kol, S. (2012). Okul öncesi öğretmenlerinin bilgisayar destekli eğitime yönelik görüşlerinin incelenmesi. Kuram ve Uygulamada Ĕgitim Bilimleri, 12(2), 887-903.

Lankshear, C., \& Knobel, M. (2003). New technologies in early childhood literacy research: A review of research. Journal of Early Childhood Literacy, 3(1), 59-82. http://dx.doi.org/10.1177/14687984030031003

Li, X., \& Atkins, M. S. (2004). Early childhood computer experience and cognitive and motor development. Pediatrics, 113(6), 1715-1722. http://dx.doi.org/10.1542/peds.113.6.1715

Ljung, A. D., Bengtsson, L. A., \& Ottosson, T. (2005). Ways of relating to computer use in pre - school activity. International Journal of Early Years Education, 13(1), 29-41. http://dx.doi.org/10.1080/09669760500048295

Macaruso, P., \& Rodman, A. (2011). Efficacy of computer assisted instruction for the development of early literacy skills in young children. Reading Psychology, 32(2), 172-196. http://dx.doi.org/10.1080/02702711003608071

Man, L. (1997). The effects of computer-assisted instruction and teacher- assisted instruction on preschool children's 
learning of arithmetic tasks. Unpublished Master Thesis, the University of Hong Kong, Hong Kong.

Namlu, A. G. (2002). Okul öncesinde bilgisayar öğretimi. TC. Anadolu Üniversitesi Yayını, No: 1366. Eskişehir.

Nir-Gal, O., \& Klein, P. S. (2004). Computers for Cognitive Development in Early Childhood-The Teacher's Role in the Computer Learning Environment. Information Technology in Childhood Education Annual, 2004(1), 97-119.

Oğuz, E., Ellez, A. M., Akamca, G. Ö., Kesercioğlu, T. İ., \& Girgin, G. (2011). Early childhood teacher candidates’ attitudes towards computer and computer assisted instruction. Elementary Education Online, 10(3), 934-950.

Okan, Z. (2003). Edutainment: Is learning at risk? British Journal of Educational Technology 34, 255-265.

Passig, D., \& Levin, H. (1999). Gender interest differences with multimedia learning interfaces. Computers in Human Behavior, 15, 173-183. http://dx.doi.org/10.1016/S0747-5632(99)00016-3

Penuel, W. R., Pasnik, S., Bates, L., Townsend, E., Gallagher, L. P., Llorente, C., \& Hupert, N. (2009). Early childhood teachers can use a media-rich curriculum to prepare low-income children for school success: Results of a randomized controlled trial. Summative evaluation of the "Ready to learn Initiative". Education Development Center. http://cct.edc.org/sites/cct.edc.org/files/ms-resources/RTLEvalReport.pdf

Şahin, B. (2006). Okul öncesi dönemde bilgisayar destekli fen öğretimi ve etkilerinin incelenmesi. Yayınlanmamış Yüksek Lisans Tezi, YediTepe Üniversitesi Sosyal Bilimler Enstitüsü.

San, P., \& Arı, M. (1988). Anaokuluna giden 5-6 yaş çocuklarında sayı ve miktar korunumunun kazandırılmasında bilgisayarla yapılan eğitimin etkisinin incelenmesi. Çocuk Sağllğı ve Eğitimi Dergisi, 3, 27-34.

Sancak, Ö. (2003). Okulöncesi eğitim kurumlarına devam eden 6 yaş çocuklarına sayı ve şekil kavramlarının kazandırılmasında bilgisayar destekli eğitim ile geleneksel eğitim yöntemlerinin karşıllaştırılması. Yayımlanmamış Yüksek Lisans tezi, Gazi Üniversitesi, Eğitim Bilimleri Enstitüsü, Ankara.

Sandberg, A. (2002). Preschool teacher's conceptions of computers and play. Information Technology in Childhood Education Annual, 1, 245-263.

Scoter, J. V., Ellis, D., \& Railsback, J. (2001). Technology in Early Childhood Education: Finding the Balance. Portland, OR: Northwest Regional Educational Laboratory.

Sprigle, E. J., \& Schaefer, L. (1984). Age, gender and spatial knowledge influences on preschoolers' computer programming ability. Early Child Development and Care, 14, 243-250. http://dx.doi.org/10.1080/0300443840140306

Stevenson, H. J., \& Hackett, R. K. (2009). Should four-year olds use computers to develop emergent literacy skills?: a study of the waterford early reading program. The Journal of Literacy and Technology, 10(2), 64-84.

Tondeur, J., Van Braak, J., \& Valcke, M. (2007). Towards a typology of computer use in primary education. Journal of Computer Assisted Learning, 23, 197-206. http://dx.doi.org/10.1111/j.1365-2729.2006.00205.x

Tracey, D. H., \& Young, J. W. (2007). Technology and early literacy: The impact of an integrated learning system on high-risk kindergartners' achievement. Reading Psychology, 28(5), 443-467.

http://dx.doi.org/10.1080/02702710701568488

Tuğrul, B. (2005). Çocuk gelişiminde anaokulu eğitiminin önemi. Bilim ve Aklın Aydınlı̆̆ında Eğitim Dergisi, 62.

Vernadakis, N., Avgerinos, A., Tsitskari, E., \& Zachopoulou, E. (2005). The Use of Computer Assisted Instruction in Preschool Education: Making Teaching Meaningful. Early Childhood Education Journal, 33(2), 99-104. http://dx.doi.org/10.1007/s10643-005-0026-2

Vorkapić, S. T., \& Milovanović, S. (2012). Computer use in pre-school education: The attitudes of the future pre-school teachers in Croatia. Education 3-13: International Journal of Primary, Elementary and Early Years Education, 42(2), 217-229. http://dx.doi.org/10.1080/03004279.2012.673003

Wilson, C. G. (2004). Seymour Papert's Vision for Early Childhood Education? A Descriptive Study of Head Start and Kindergarten Students in Discovery-based, Logo-rich Classrooms. Early Childhood Research \& Practice, 6(1).

Yaşar, Ş. (2004). Okul öncesi eğitimde bilgisayarın yeri ve önemi. A.G.Namlu (Ed.), Okul öncesinde bilgisayar öğretimi içinde (s.1-10). Eskişehir: Anadolu Üniversitesi Yayınları.

\section{$(\mathrm{cc}) \mathrm{EY}$}

This work is licensed under a Creative Commons Attribution 3.0 License. 